museums at present participating in the scheme are the Victoria and Albert, Horniman and Geffrye Museums. Dr. Malcolm, who was a research scholar in anthropology of Christ's College, Cambridge, and obtained his Ph.D. degree for a thesis on the history and development of medical museums, not only has a wide and varied experience of museum work, but he has also devoted much attention to the practical development of the museum collection as a part of the machinery of education. His work will be supported by a strong and informed committee of the County Council.

\section{Research on Carcinogenic Compounds}

THE thirty-first Bedson Lecture was delivered by Prof. J. W. Cook, of the Cancer Hospital, London, to the Bedson Club at Armstrong College, Newcastleon-Tyne, on November 8. Prof. Cook took as his subject "The Synthesis and Biological Effects of Carcinogenic Hydrocarbons", and said it has long been known that certain forms of skin cancer are due to occupational causes, such cases being prevalent among workers in the coal-tar and allied industries, in the shale oil industry and among mule spinners in cotton mills. This is due to the action of a common constituent of coal tar, and shale and lubricating oil, the isolation and identification of which was successfully accomplished about three years ago in the research laboratories of the Cancer Hospital, London. A very valuable guide in the difficult task of separating this substance from the other constituents of the mixtures was provided by the fact that these tars and oils having carcinogenic properties are all strongly fluorescent. An investigation of the nature of this fluorescence spectrum directed attention to the benzanthracene group of hydrocarbons. Many of these have been prepared artificially in the laboratory, and some have been shown capable of producing cancer in mice. The cancer-producing constituent of coal tar, etc., benzpyrene, belongs to this group. More recently, it has been found possible to bring about the artificial conversion of substances normally present in the human body, namely, cholic and deoxycholic acids, into a hydrocarbon of the benzanthracene type, methylcholanthrene, and this was found to be more powerfully cancer-producing than any other substance yet investigated. The chemical changes by which it was obtained are of the type which are well known to occur in the body, and it may be that cancer in man is due to some such substance as a bile acid undergoing decomposition in an abnormal manner, with conversion into cancer-producing substances.

\section{Chemistry in the Universities and Schools}

"THE Teaching of Chemistry" was the subject chosen by Prof. Arthur Smithells, director of the Salters' Institute of Industrial Chemistry, for his Harrison Memorial Lecture to the Pharmaceutical Society on November 12. The chief difficulty of the university professor of chemistry lies in dealing with a subject in which the advance has been of unparalleled rapidity and, most recently, in changes on the theoretical side which have not only led to the acquisition of tracts of now knowledge, but also have affected science at its very base. Prof. Smithells believes that these advances have placed a great burden on the student, and especially on his memory. The reduction and emendation of the curriculum would result in a gain far exceeding in importance any possible loss in its range. Passing to the teaching of chemistry to those whose dominant interest is its application to some particular calling, reference was made to students of medicine as an example. Prof. Smithells himself had placed such students in a course apart, where he had striven, without any intellectual sacrifice, to invest the teaching throughout with facts and illustrations connected with the medical calling. The teaching of chemistry in schools, after a period of rapid growth, became a mere smallscale replica in contents and form of the early chemical course of a university. This teaching led to the revolt, headed by Prof. H. E. Armstrong, who from then to the present day has stood as the great campaigner against all that has seemed unsound in chemical education, wherever it has appeared, but, above all, in its earlier stages. The influence exerted inevitably by the university teacher has been far beyond what is warranted. Relief of the crowded curriculum has been sought by relegating to the schools so much higher work in science that there is a real danger existing of just that kind of over-balance of one kind of subject, as was the case with classics when science first sought admission to the curriculum.

\section{Weights and Balances in Ancient Egypt}

Ar the Friday evening discourse at the Royal Institution on November 8, Prof. S. R. K. Glanville discussed "Weights and Balances in Ancient Egypt". The actual weights recovered from Ancient Egypt divide into eight main standards, derived from a much larger number in very early times. What we have go back to prehistoric times and show a gradual fusion of the standards, a process which is completed by the seventh century B.C. The balance may be traced from the Old Kingdom, with a possible example of a balance beam from pre-dynastic times. The Now Kingdom balance, which lasted at any rate until the Ptolemaic period, was very efficient, and shows a greater accuracy in its design than the small Roman balance which succeeded it. There is evidence of a standard of exchange in ordinary transactions from the Old Kingdom, though whether this standard was a piece of metal, which could be passed between buyer and seller, is questionable at this period. The explanation of the lack of evidence for such mediums of exchange is probably in the nature of the organisation of the country in earliest times as a huge estate owned by the king, and later as a number of big estates controlled by governors and priesthoods, a condition which to some extent exists to-day. These estates being largely self-sufficing, it was possible to conduct their economic affairs without resort to anything approaching currency. There is, however, evidence of the use in the Middle Kingdom of copper pieces, and of a much more frequent use in the New 